\title{
Effects of the passage of cold fronts over a coastal site: an ecosystem approach
}

\author{
Fabiane Gallucci, Sérgio A. Netto* \\ Laboratório de Ciências Marinhas, Universidade do Sul de Santa Catarina (UNISUL), Av. Colombo Sales 84, Laguna, \\ Santa Catarina, 88790-000, Brazil
}

\begin{abstract}
The effects of 2 cold fronts on a shallow sublittoral system at the Island of Santa Catarina, southern Brazil, were investigated in June 2002. Atmospheric, pelagic and benthic data were taken daily covering the days before, during and after the passage of both fronts, for a total of $8 \mathrm{~d}$ of sampling. The passage of cold fronts, a short-term event, promotes changes in the entire shallow sublittoral ecosystem, i.e. both pelagic and benthic compartments. In the pelagic system, both fronts changed seston, nutrient and chl a concentrations. An increase in chl a just after the passage of the fronts probably resulted from phytoplankton retention and accumulation near the coast, from microphytobenthos resuspension and from an increase in nutrient availability. In the benthic system, sediment features and the 3 benthic components studied-microphytobenthos, meiofauna and macrofauna - were also affected by the passage of the cold fronts. The sediments at the site became more homogeneous. While mean grain size decreased, the fraction of fine sand gradually increased after the passage of the fronts. In contrast, sediment organic content was significantly higher immediately after the passage of the first cold front. Cold front effects in the benthos depended on the biological component, the vertical distribution of fauna and on the magnitude of the front. The sediment chl $a$ concentration was lower exactly $1 \mathrm{~d}$ after the passage of the fronts, while phaeopigments were significantly higher. Both macrofauna and meiofauna, particularly nematodes, of the upper sediment layer exhibited a decrease in density and number of taxa during the passage of the first frontal system. The decrease in nematode abundance was mostly due to vertical migration to the deeper layers of the sediment, rather than being the result of erosion and transport during the passage of the cold fronts.
\end{abstract}

KEY WORDS: Cold front $\cdot$ Short-term disturbance $\cdot$ Phytoplankton $\cdot$ Microphytobenthos $\cdot$ Meiofauna Nematodes $\cdot$ Macrofauna

Resale or republication not permitted without written consent of the publisher

\section{INTRODUCTION}

In meteorology, a front is defined as a boundary between 2 air masses of different characteristics, such as density (Varejão-Silva 2001). Since temperature is the most important factor determining atmospheric density, a front almost invariably separates air masses of different temperatures. A cold front is the boundary of a cold air mass advancing over a warm surface. The passage of cold fronts, a short-term atmospheric disturbance, modifies the relationships among marine boundary systems through interactions between the atmosphere and the ocean, and between the water column and the sea floor.
In southern Brazil, passage of cold fronts is a common event throughout the year (mean of 5 to 6 per mo), with a higher frequency and intensity in the winter (CPTEC: Centro de Previsão do Tempo e Estudos Climáticos, INPE (Instituto Nacional de Pesquisas Espaciais), available at www.cptec.inpe.br/prevnum/). The cold fronts propagate from SW to NE over the South Brazilian Bight (SBB; Fig. 1) at an average speed of $500 \mathrm{~km} \mathrm{~d}^{-1}$, crossing the region in $2 \mathrm{~d}$ (Stech \& Lorenzetti 1992). In the region that precedes the front (the warm sector), the wind blows from NE with a mean velocity of $5 \mathrm{~m} \mathrm{~s}^{-1}$. As the cold front approaches, the wind rotates counterclockwise to NW (Fig. 1b). Immediately after the passage of the front, the wind 


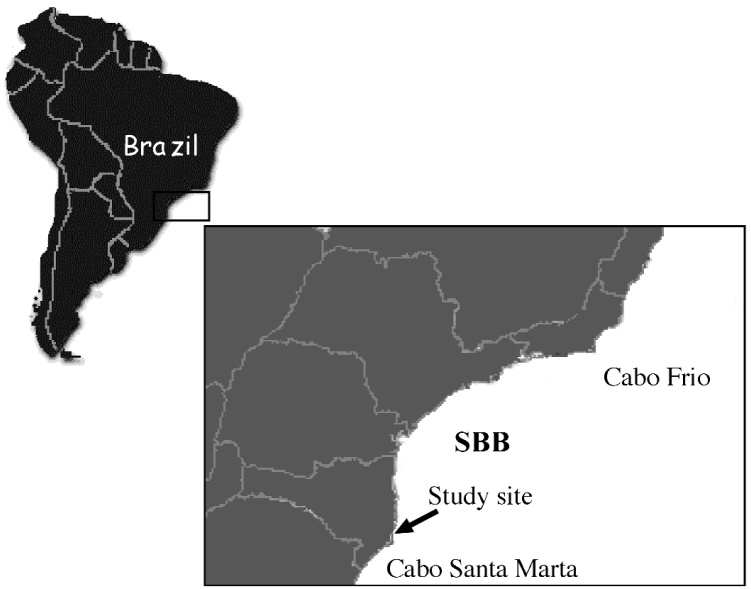

b

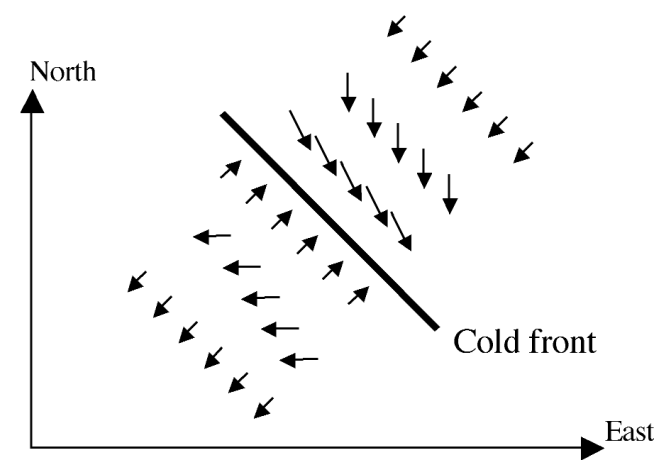

Fig. 1. (a) South Brazil Bight (SBB) and position of the Island of Santa Catarina. (b) Conceptual model of the passage of a cold front (after Stech \& Lorenzetti 1992) over the study area. Arrows indicate the wind direction

blows from SW (in the cold sector) with a mean speed of $8 \mathrm{~m} \cdot \mathrm{s}^{-1}$. Approximately $1 \mathrm{~d}$ after the passage of the front the wind returns to its predominant NE direction (see Fig. 1b).

The surface wind field along the SBB is strongly influenced by the passage of frontal systems (Stech 1990). Considering that wind stress is one of the major low-frequency forcing mechanisms of the coastal circulation (Stech \& Lorenzetti 1992), the frontal systems are expected to play a significant role in structuring the dynamics of shallow marine systems. However, effects of the passage of cold fronts on marine systems have thus far been inferred rather than documented (Odebrecht et al. 1995b, Sunyé 1999).

This paper reports on the effects of the passage of cold fronts in a shallow sublittoral system of the Island of Santa Catarina, S Brazil. The study evaluates shortterm changes in abiotic and biotic water columns and sediment characteristics, as well as the interactions between atmospheric, pelagic and benthic systems, caused by the passage of cold fronts and the associated wind fields.

\section{MATERIAL AND METHODS}

Sampling. The study was carried out at a shallow sublittoral site $(1 \mathrm{~m}$ depth) off a sheltered beach located on the southern shore of the Island of Santa Catarina, South Brazil $\left(27^{\circ} 29^{\prime} \mathrm{S}, 48^{\circ} 30^{\prime} \mathrm{W}\right.$; Fig. 1). Daily sampling was conducted from 4 to 11 June 2002. The sampling covered periods before (Days -2 and -1 ), during (Day 0) and after the passage of a cold front (Days 1, 2 and 3). After the last sampling day (Day 3), another cold front swept over the study area and sampling was continued for 2 more days (Days 4 and 5), for a total of $8 \mathrm{~d}$ of continuous sampling. The sampling design required an accurate prediction of the passage of the fronts. The cold fronts were predicted by numerical models of the Meteorological Center of Santa Catarina State (CLIMERH). The CLIMERH can characterize the intensity of cold fronts $2 \mathrm{~d}$ before its arrival. Twenty-four hours prior to the passage of the cold front, the CLIMERH estimated the exact hour of the passage over the Island of Santa Catarina. On the basis of this information a sampling campaign could be initiated.

Atmospheric system. The behaviour of both cold fronts (position, displacement velocity, wind intensity and direction, air temperature, relative air humidity and air pressure) was followed in real time during the sampling period. Meteorological conditions at the Island of Santa Catarina were continuously registered by an automatic meteorological station of EPAGRI/ CLIMERH and by an automatic station of the DPV-FL at Florianópolis International Airport.

Variations in meteorological data due to the passage of the frontal systems - wind direction and velocity, air temperature, air pressure, rainfall, cloud cover, sunshine, and relative humidity - were analyzed. Hourly wind direction data served to determine the predominant wind of each day. The mean velocity of southerly winds was determined by the simple mean of the SW, $\mathrm{S}$ and SE wind components. For both estimates (predominant wind and south wind mean velocity), the period between sampling occasions was considered as $1 \mathrm{~d}$, i.e. the hour of sampling determined the end of one day and the beginning of the next. Satellite images (NOAA 2002: National Oceanic \& Atmospheric Administration; www.noaa.org/satellites.html) were analyzed in addition to the meteorological data.

Pelagic system. Salinity and water temperature were measured in situ. On each sampling day 2 water samples were taken and transported to the laboratory in $500 \mathrm{ml}$ polyethylene bottles for analysis of seston, nutrients, chl $a$ and phaeopigments. One of the samples was filtered through a dry and pre-weighed glassfibre filter Whatman GF/052C $(0.45 \mu \mathrm{m}$ nominal pore size) for seston determination. The second water 
sample was filtered through a second glassfibre filter, and the water was used for determination of dissolved inorganic nutrients (silicate, phosphate, nitrite and nitrate) according to Strickland \& Parsons (1972). The second filter was stored frozen $\left(-12^{\circ} \mathrm{C}\right)$; acetoneextracted chl a was later determined photometrically according to Strickland \& Parsons (1972) and chl a concentrations were estimated following SCORUNESCO (1966).

Benthic system. For all the benthic components analyzed-microphytobenthos, meiofauna and macrofauna -4 samples were taken on each sampling day. For microphytobenthos analyses, the surface centimetre was sampled with a $1 \mathrm{~cm}$ diameter core tube. Pigments were extracted with $90 \% \mathrm{v} / \mathrm{v}$ acetone and analyzed according to Strickland \& Parsons (1972). Chl a and phaeopigments concentrations were estimated using Lorenzen's (1967) equation. Meiofauna samples were taken with a plastic syringe $(2 \mathrm{~cm}$ in diameter to a depth of $10 \mathrm{~cm}$ ) and sectioned into 0 to $5 \mathrm{~cm}$ and 5 to $10 \mathrm{~cm}$ subsamples. Samples were immediately fixed in $4 \%$ formalin and later sieved through a $63 \mu \mathrm{m}$ mesh and extracted by flotation with Ludox TM (specific gravity: 1.15; De Jonge \& Bouwman 1977). Samples were then evaporated with anhydrous glycerol and permanent slides were made (Somerfield \& Warwick 1996). For the macrofauna, samples were taken with a $10 \mathrm{~cm}$ diameter core tube pushed into the sediment to a depth of $5 \mathrm{~cm}$ and immediately fixed in $10 \%$ formalin. Fixed samples were sieved through a $0.5 \mathrm{~mm}$ mesh, and sorted under a stereomicroscope. All invertebrates were identified to the lowest possible taxonomic level.

Additionally, 3 samples for sediment granulometry and total organic content were taken on each sampling day with a $10 \mathrm{~cm}$ diameter corer inserted to a depth of $5 \mathrm{~cm}$. Sediment granulometry was determined by sieving dried samples (Suguio 1973), and total organic content by oxidation (Carver 1971).

Data analysis. Univariate and non-parametric multivariate techniques used are described in Clarke \& Warwick (1994). For the meiofauna, nematodes and macrofauna, univariate measures included number of taxa $(\mathrm{S})$, density $(\mathrm{N})$ and Shannon-Wiener diversity indices calculated using $\log _{2}\left(\mathrm{H}^{\prime}\right)$. Chl $a$ and phaeopigment concentrations were used as descriptors for the microphytobenthos. Sediments were characterised by mean grain size, fine sand fraction and organic content. Differences in univariate measures (fauna, microphytobenthos and sediments) between days were tested by 1-way ANOVA. Univariate 2-way ANOVA was used to test for differences in nematode univariate measures for Days (Days -2 to 5), Sediment strata ('upper', 0 to $5 \mathrm{~cm}$; 'lower', 5 to $10 \mathrm{~cm}$ ), and Days Sediment strata. A 'split-plot' design was constructed with replicates nested within Days, but not within Sediment strata. Cochran's $C$ tests were applied to test for homogeneity of variances, and data were $\log (\mathrm{x}+1)$ transformed where necessary. Tukey multiple comparison tests were used when significant differences were detected ( $p<0.05$; Sokal \& Rohlf 1997).

Similarity matrices were constructed using BrayCurtis similarity measure on faunistic data. Ordination was by non-metric multidimensional scaling (MDS) and formal significance tests for differences between days were performed using the ANOSIM permutation test (Clarke \& Green 1988). Although it is important to obtain information on replicate variability, averaging samples increases the signal-to-noise ratio for displaying patterns of change in relation to a disturbance (Somerfield et al. 1995). For this reason, and because MDS stress was too high (>0.3) when using all the replicates, both meio- and macrofauna abundances from the 4 replicates for each day were averaged for MDS analysis. The variability amongst replicate samples was analyzed using the multivariate relative dispersion measure, a procedure used by Warwick \& Clarke (1993) to examine an increase in variability between sample replicates with increased levels of perturbation.

Environmental data from the atmospheric, pelagic and benthic systems were ordinated using a correlation based principal component analysis (PCA). The relationships between multivariate community structure and combinations of environmental variables were analyzed using the BIO-ENV procedure (Clarke \& Ainsworth 1993) to define suites of variables that best explain the faunistic structure.

\section{RESULTS}

\section{Atmospheric system}

Satellite images of each sampling day showed that between Days -2 and -1 a cold front located over southern Brazil moved northward, passing through the study area on Day 0. On Day 1 the front moved offshore. On Day 3 another cold front arrived over the southern part of Brazil, passing through the study area on Day 4. During Day 5 this second cold front remained semi-stationary offshore.

Meteorological conditions at the Island of Santa Catarina during the sampling period are shown in Fig. 2. Atmospheric pressure decreased before the passage of both cold fronts (Days -2 and 3 ). After the passage of the fronts (Days 1 and 5 ), atmospheric pressure increased and air temperature decreased. These changes were particularly pronounced before and after the second cold front (Fig. 2). Relative humidity 

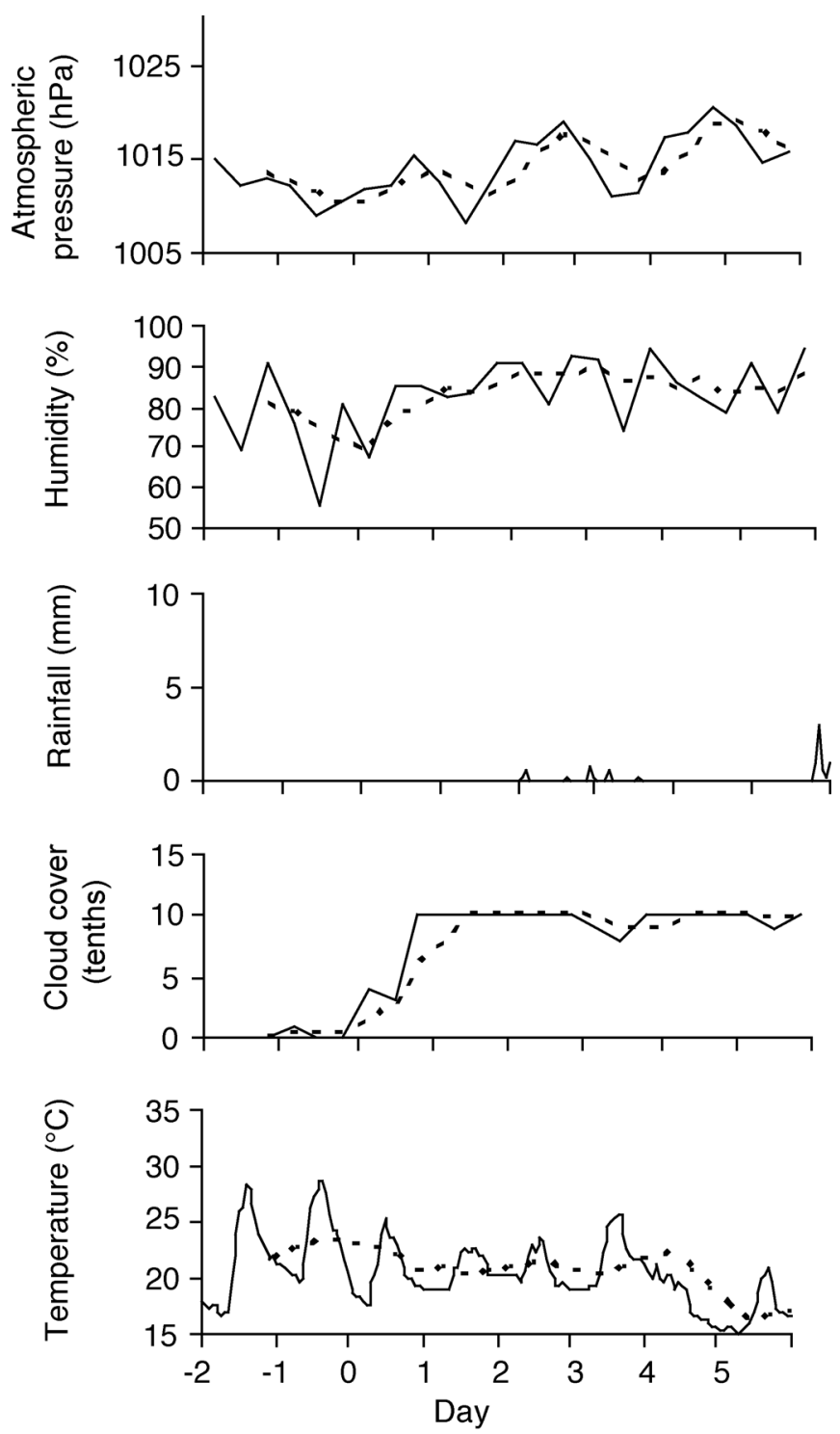

Fig. 2. Atmospheric pressure, humidity, rainfall, cloud cover and air temperature. Dashed lines represent the moving average for $24 \mathrm{~h}$ data $\mathrm{s}^{-1}$ ). As a consequence of the passage of the second cold front, winds shifted southerly again (Days 4 and 5). However, the mean intensity of the wind on Day 4 (second front) was $4.1 \mathrm{~m} \mathrm{~s}^{-1}$, less than for the first cold front (Fig. 3).

\section{Pelagic system}

During the sampling period, water temperature and salinity varied little (Fig. 4). Seston concentration was higher on Days 0, 4 and 5, during the passage of both cold fronts. Chl a concentration in the water column showed an increase at Day 0 reaching a maximum value on Day 1 (3.26 $\left.\mathrm{g} \mathrm{l}^{-1}\right)$, just after the passage of the first cold front. Both seston and chl a showed lower values on Day 3, increasing again on Day 4, during the passage of the second front. Silicate concentrations oscillated between 7.8 and $23.8 \mu \mathrm{M}$ and exhibited 2 peaks: on Day 0, during the passage of the first cold front and on Day 5 , just after the passage of the second frontal system. Total nitrogen (nitrate + nitrite) showed an opposite pattern, with a decrease in concentration on Days 1 and 4 (Fig. 4). Phosphate concentrations varied little during the sampling period. Nutrient concentrations on Day 3 are missing.

\section{Benthic system}

\section{Microphytobenthos}

Chl a concentration in the surface sediment ranged between 0 and $7.82 \mathrm{mg} \mathrm{cm}^{-3}$ and was significantly lower on Days 1 and 5, immediately after the passage of the two fronts (ANOVA $\mathrm{p}<0.05$, HSD test; Fig. 5). Phaeopigments showed an opposite pattern, with significantly higher concentrations on Days 1 and 5 $(\mathrm{p}<0.05)$.

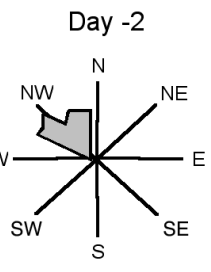

Day 2

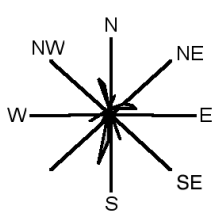

Day-1

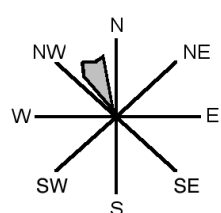

Day 3

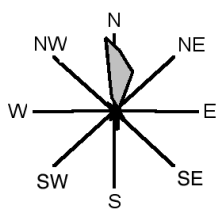

Day 0

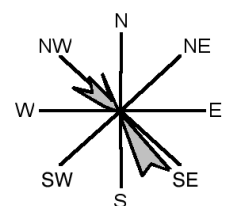

Day 4

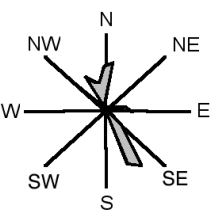

Day 1

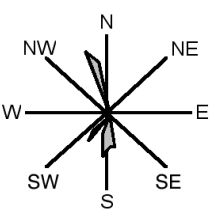

Day 5

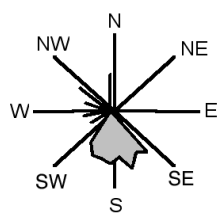

Fig. 3. Wind direction and intensity 

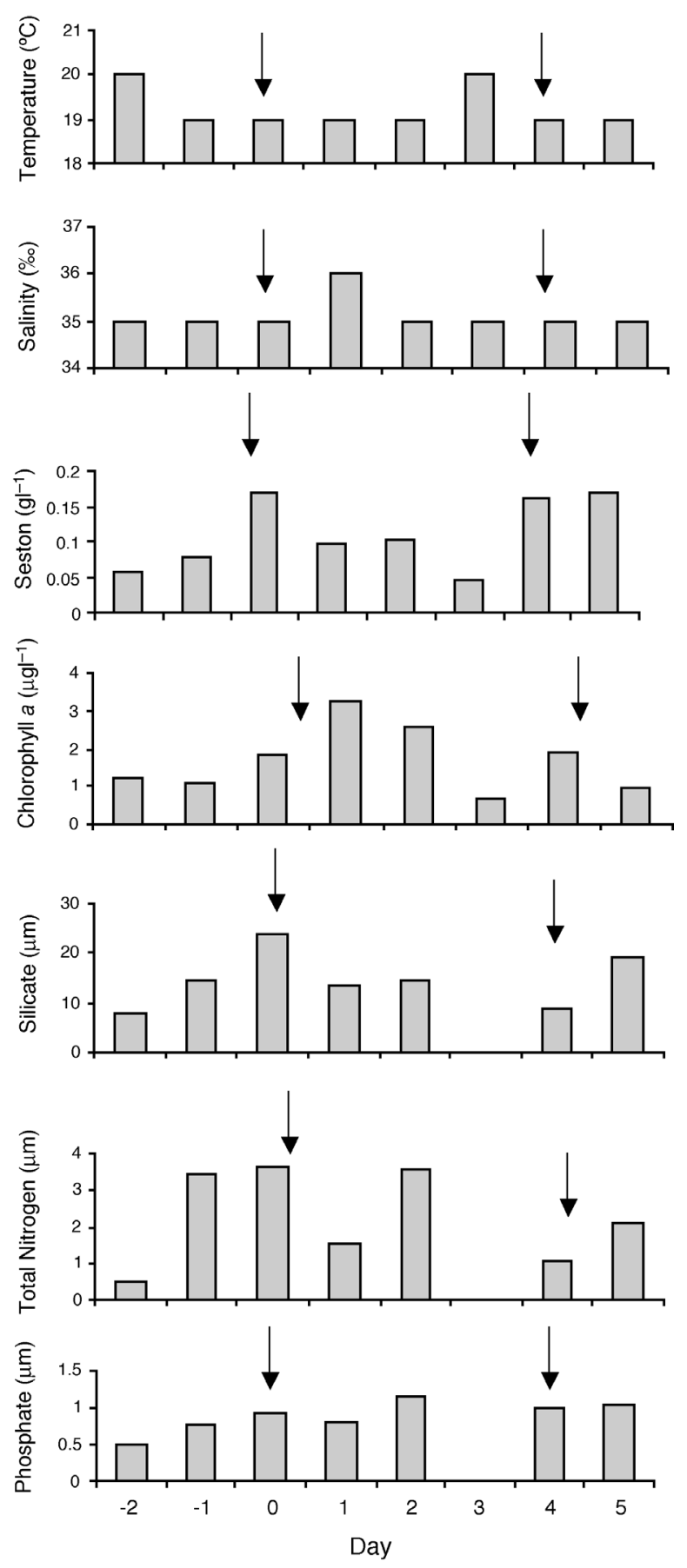

Fig. 4. Water temperature, salinity, seston, chlorophyll $a_{\text {, }}$ silicate, total nitrogen and phosphate concentrations. Arrows indicate passage of the cold fronts

\section{Fauna}

The univariate measures derived from the fauna differed among days. However, the differences in the number of taxa, density and diversity (ShannonWiener index) among days depended on the faunistic
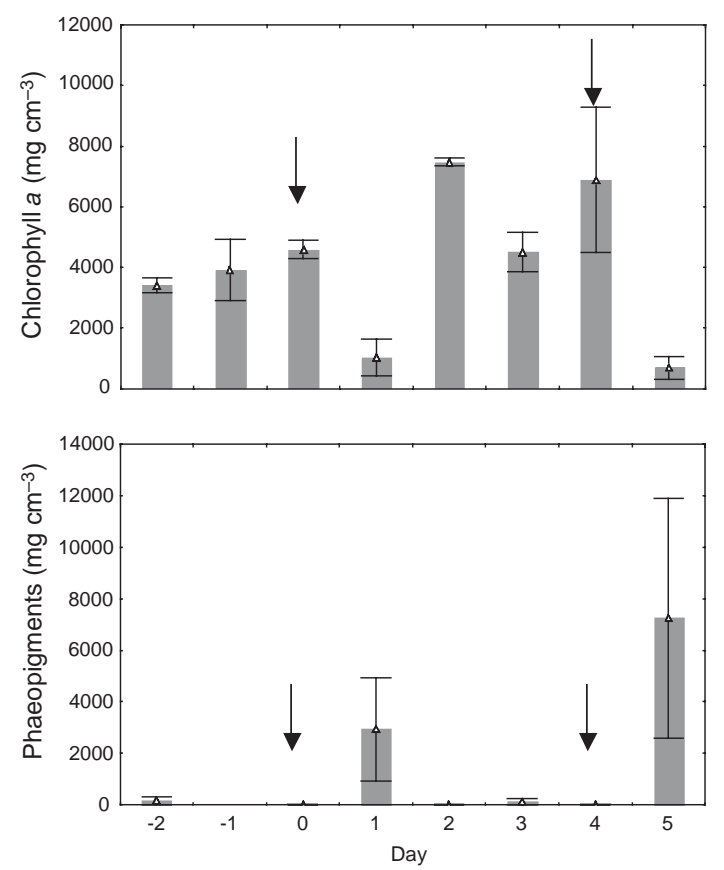

Fig. 5. Sediment chlorophyll $a$ and phaeopigment concentrations (mean $\pm \mathrm{SE}$ ). Arrows indicate passage of the cold fronts

component analyzed. In the same way, the multivariate analysis derived from the fauna also differed among days and varied according to the benthic component.

Macrofauna. Thirty macrobenthic taxa were identified, with maximum densities up to 4500 ind. $\mathrm{m}^{-2}$. The polychaetes Leitoscoloplos sp. 1. and Armandia sp. 1. numerically dominated the samples, accounting for $81 \%$ of the total.

Before the arrival of the first cold front (Days -2 and -1 ), all univariate measures derived from macrofauna were similar ( $p>0.05$; HSD test). During the passage of the front (Day 0) macrofauna density, number of species, and diversity decreased significantly (Fig. 6); $24 \mathrm{~h}$ later (Day 1) all values were back to pre-frontal conditions. During the passage of the second cold front (Day 4 ), both mean density and total number of taxa decreased, though not significantly ( $p>0.05$, Fig. 6). On Day 5, a significant increase in macrofauna univariate measures was observed.

MDS ordination (Fig. 7a) showed a clear distinction between Day 0 and all the other days. The ANOSIM test confirmed this difference. A second-stage MDS (Fig. 7b) did not reveal any differentiation of the macrofauna communities between pre- and postfrontal situations.

Meiofauna. The density and the number of meiobenthic taxa varied between the upper ( 0 to $5 \mathrm{~cm}$ ) and lower strata $(5$ to $10 \mathrm{~cm})$. In the upper stratum, 9 meiobenthic higher taxa were identified, with densities ranging from 

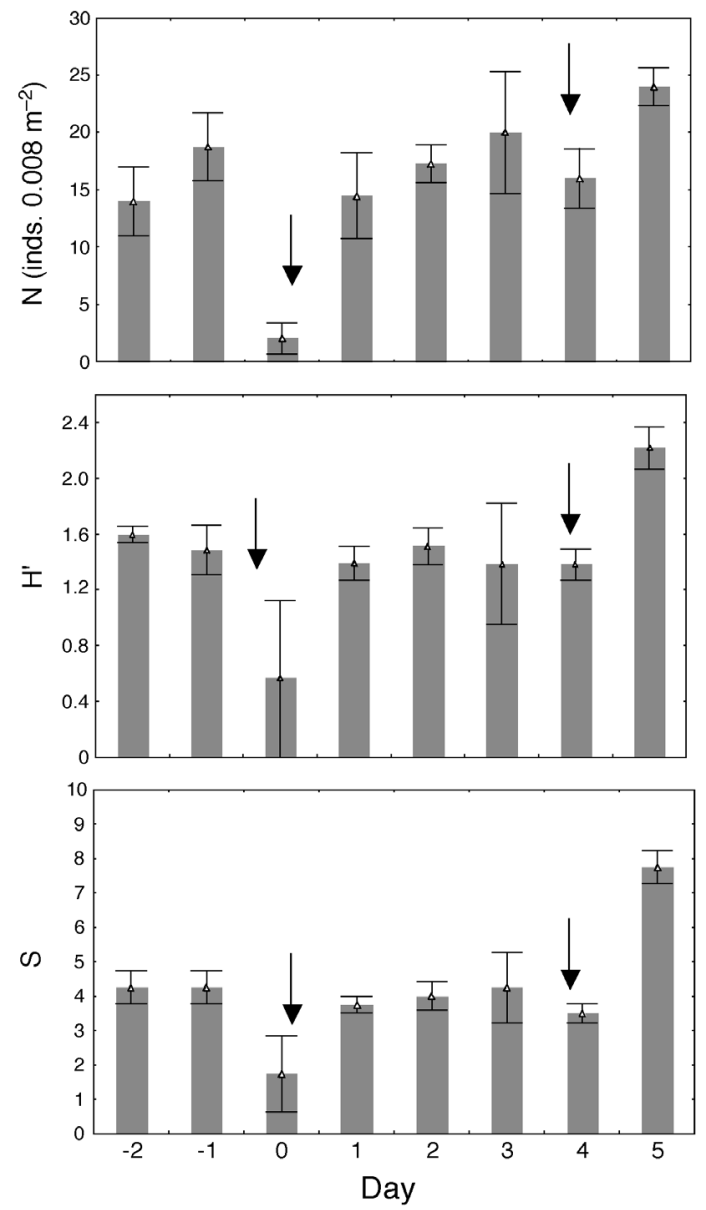

Fig. 6. Univariate measures (mean $\pm \mathrm{SE}$ ) of macrofauna: total density (N), number of taxa (S), Shannon-Wiener diversity $\left(\mathrm{H}^{\prime}\right)$. Arrows indicate passage of the cold fronts

a

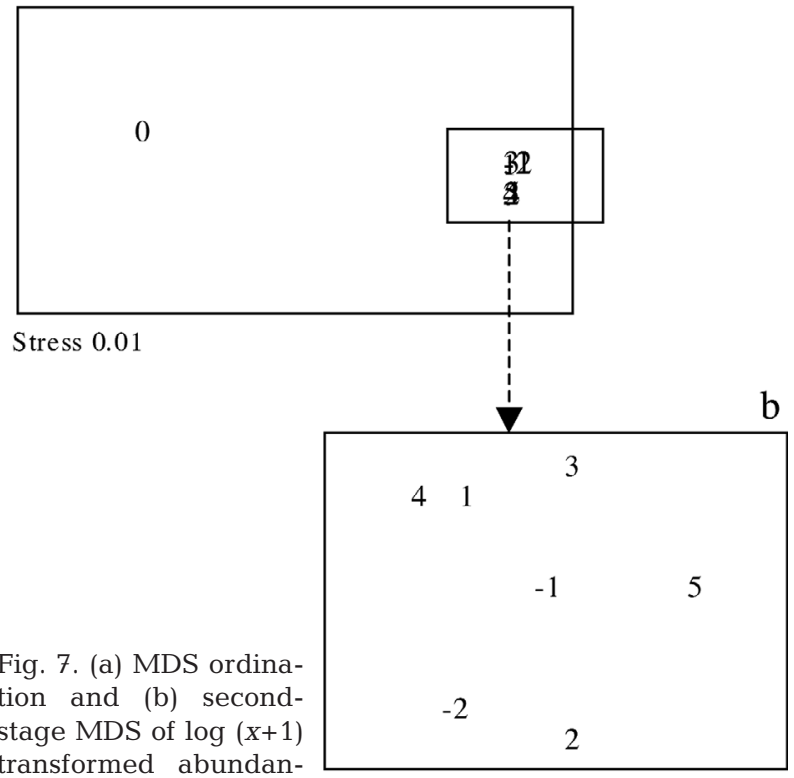

transformed abundances of macrofauna
8.0 to 50.3 ind. $10 \mathrm{~cm}^{-2}$. Yet in the lower stratum, 6 meiobenthic groups were recorded, with densities between 2.2 and 22.6 ind. $10 \mathrm{~cm}^{-2}$. Organisms from the upper $5 \mathrm{~cm}$ of the sediment represented $76 \%$ of the total meiofauna. The nematodes dominated both strata, accounting for $61 \%$ and $95 \%$ of the total number of organisms in the upper and lower strata, respectively. Copepods had the second highest numerical importance in the upper stratum, where they accounted for $36 \%$ of the total. In the lower stratum, copepods (including nauplii) represented only $2.7 \%$ of the meiofauna. Other groups such as amphipods, polychaetes and oligochaetes were recorded exclusively in the surface layer. Only the nematodes were recorded in all samples.

Before the passage of the first cold front (Days -2 and $-1)$, both meiofauna density and number of taxa did not show any significant difference $(p>0.05$, HSD test; Fig. 8a,b). During the passage of the first front (Day 0) meiofauna density decreased significantly $(p<0.05$; Fig. 8a). One day later (Day 1 ), density was back to previous levels. However, meiofauna densities decreased again on Day 3 (Fig. 8a). During the passage of the second front (Day 4) density increased significantly once more and remained constant until the end of the study (Fig. 8a). The number of meiofauna taxa remained constant until the passage of the second cold front (Day 4 ), when it increased significantly (Fig. 8a).

Regarding the vertical distribution of the meiofauna (Fig. 8), there were great differentces between sediment strata. Whilst the decrease of the densities observed at Day 0 and Day 3 (10 cm integrated, Fig. 8a) occurred at the upper stratum, the increase in the number of taxa and density on Day 4 occurred in the lower stratum (Fig. 8b).

MDS ordination (10 $\mathrm{cm}$ integrated, and split into 2 strata) did not show any clear distinction between preand post-frontal situations (Fig. 9). The results of the ANOSIM tests confirmed the lack of differences between pre- and post-frontal meiofauna community structure $(p>0.05)$.

Nematodes. A total of 57 genera belonging to 24 families were recorded. Odontophora (Axonolaimidae), Omicronema and Pseudosteineria (both Xyalidae) numerically dominated, accounting for $35 \%$ of all the individuals collected. Xyalidae was the family with the greatest number of genera and represented $40 \%$ of the nematodes. From all the nematodes collected, $73 \%$ were recorded at the upper $5 \mathrm{~cm}$ of the sediment.

The patterns of change in nematode densities were similar to those observed for meiofauna: a significant decrease during the passage of the first cold front (Day 0) and a subsequent increase 24 h later. However, nematode densities on Days 1 and 2 reached values significantly higher than before the passage of the first front (Fig. 10a). A new reduction in the nematode den- 

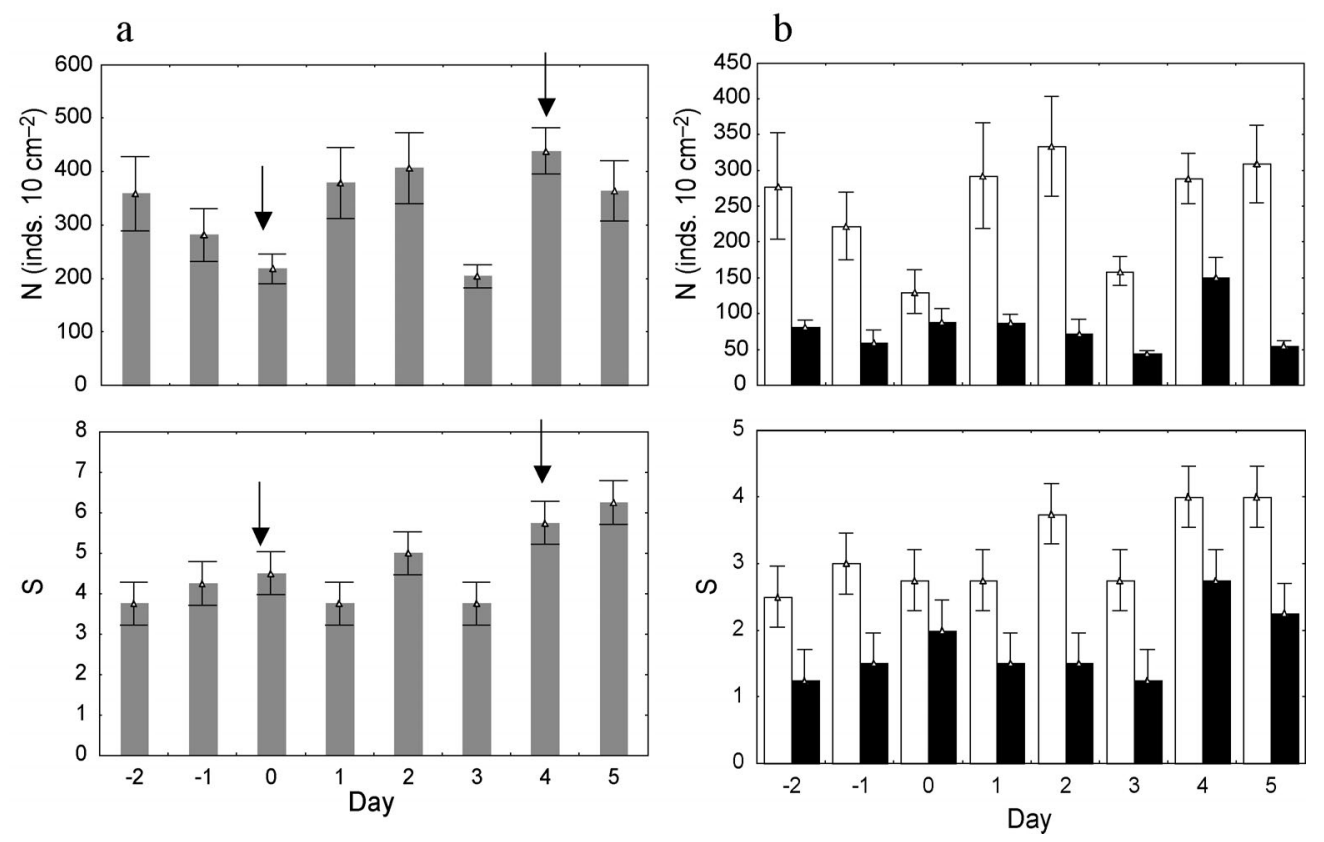

Fig. 8. Meiofauna, total density (N) and number of taxa (S); (a) $10 \mathrm{~cm}$ integrated sediment (grey bars), (b) upper stratum (white bars) and lower stratum (black bars). Data are mean \pm SE. Arrows indicate passage of the cold fronts

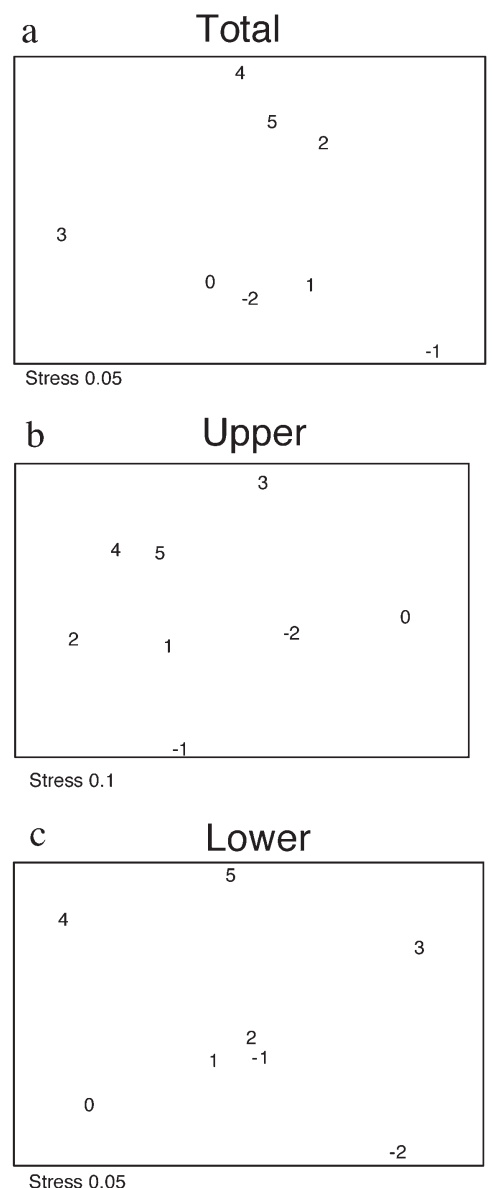

Fig. 9. MDS ordination of transformed meiofauna abundances: (a) $10 \mathrm{~cm}$ integrated sediment, (b) upper stratum, (c) lower stratum sities occurred on Day 3, followed by an increase on Days 4 and 5. Nematode densities in the upper stratum varied in the same way as those in the $10 \mathrm{~cm}$ integrated data. In the lower stratum, densities were higher on Day 4 ( $\mathrm{p}<0.05$, HSD test; Fig. 10b).

The number of nematode genera remained constant until the passage of the second cold front (Day 4), when it increased significantly (Fig. 10a). However, this constancy was apparent only for the $10 \mathrm{~cm}$ integrated data. Regarding the vertical distribution of the nematodes, the passage of the first cold front caused a significant decrease in nematode taxa in the upper stratum and an increase in the lower stratum $(p<0.05$, HSD test; Fig. 10b). Nematode diversity showed a similar pattern to that observed for the total number of genera. The results of the 2-way ANOVA tests for nematode densities, number of taxa and diversity showed significant interactions between the factors Days and Sediment strata (Fig. 11).

Among the numerically dominant nematode genera, Odontophora, Microlaimus and Spirinia showed significant differences among sampling days $(\mathrm{p}<0.05$, HSD test; Fig. 12). In the upper stratum, Microlaimus and Spirinia showed a significant reduction in densities during the passage of the first front, followed by a significant increase on Day 1. These species showed the same oscillation until the end of the sampling period (Fig. 12). The genus Odontophora did not show a decrease in density with the passage of the first front but increased significantly on Days 1 and 2. MDS ordination of forth-root transformed nematode genera in the $10 \mathrm{~cm}$ integrated data showed a distinction in com- 

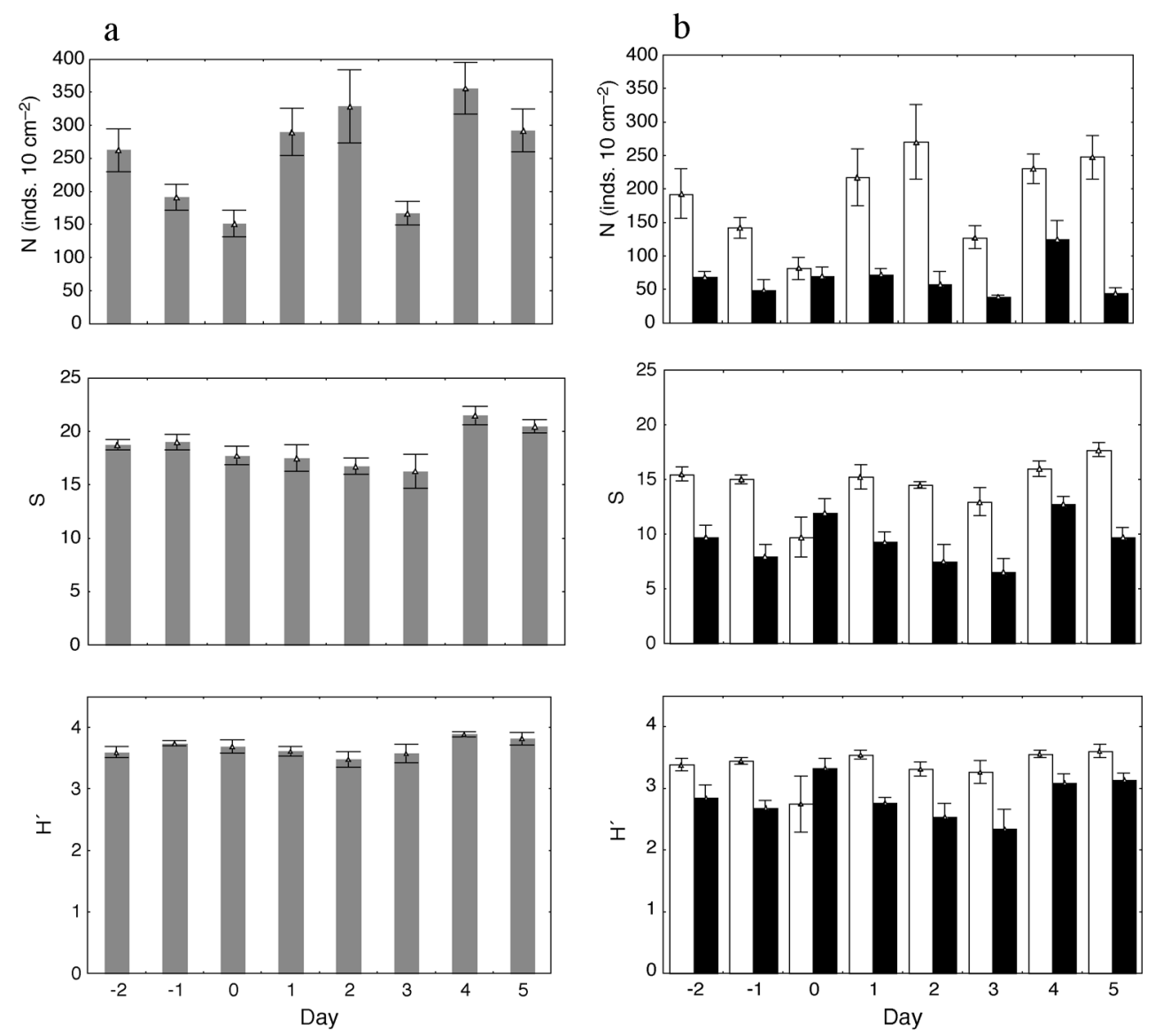

Fig. 10. Nematode, total density (N), number of genera (S), Shannon-Wiener diversity (H') ; (a) 10 cm integrated sediment (grey bars), (b) upper stratum (white bars) and lower stratum (black bars). Data are mean \pm SE

munity structure among the periods before, during and after the passage of the cold fronts (Fig. 13a). For the upper stratum, meiofauna community structure at Day 0 clearly differed from that of the remaining days (Fig. $13 \mathrm{~b})$. In the second stage MDS, the sequential change in the nematode community structure becomes apparent (Fig. 13c). In the lower stratum, nematodes were only distinct on Day 4 during the passage of the second cold front (Fig. 13d).

The variability between sample replicates, showed by the multivariate relative dispersion, decreased in both strata after the passage of the cold front (Day 0) and during the passage of the second cold front (Day 4) (Fig. 14).

\section{Sediment}

Sediments at the sampling site were characterized by fine sand. The sorting values ranged from moderate to well sorted and did not show significant differences among days. Mean grain size was significantly higher on Days -2 and -1 and lower on Days 2, 3 and 4 (Fig. 15). Percentage of fine sand was significantly higher on Days 2 and 3 (Fig. 15). Sediment organic content varied between 0.89 and $10.73 \%$. Higher values were detected on Day 1, just after the passage of the first cold front (Fig. 15).

\section{Interactions between atmospheric, pelagic and benthic systems}

PCA of the atmospheric, pelagic and benthic data showed a clear distinction among sampling days (Fig. 16). Components 1 and 2 were responsible for $59.3 \%$ of the total variability (PC1: $34.6 \%$; PC2: $24.7 \%$ ). On the first component, where distinction between the pre- and post-front conditions was evident (Fig. 16), higher positive values (Day -1 and Day -2) were associated with sunshine and air temperature and higher negative values were due to cloud cover and mean grain size. Along the second component, air temperature and fine sand percentage were responsible for the higher positive values, whilst seston and medium sand percentage were associated with higher negative values.

The interrelationships between the multivariate structure of benthic community and combinations of abiotic variables derived from the atmospheric, pelagic 

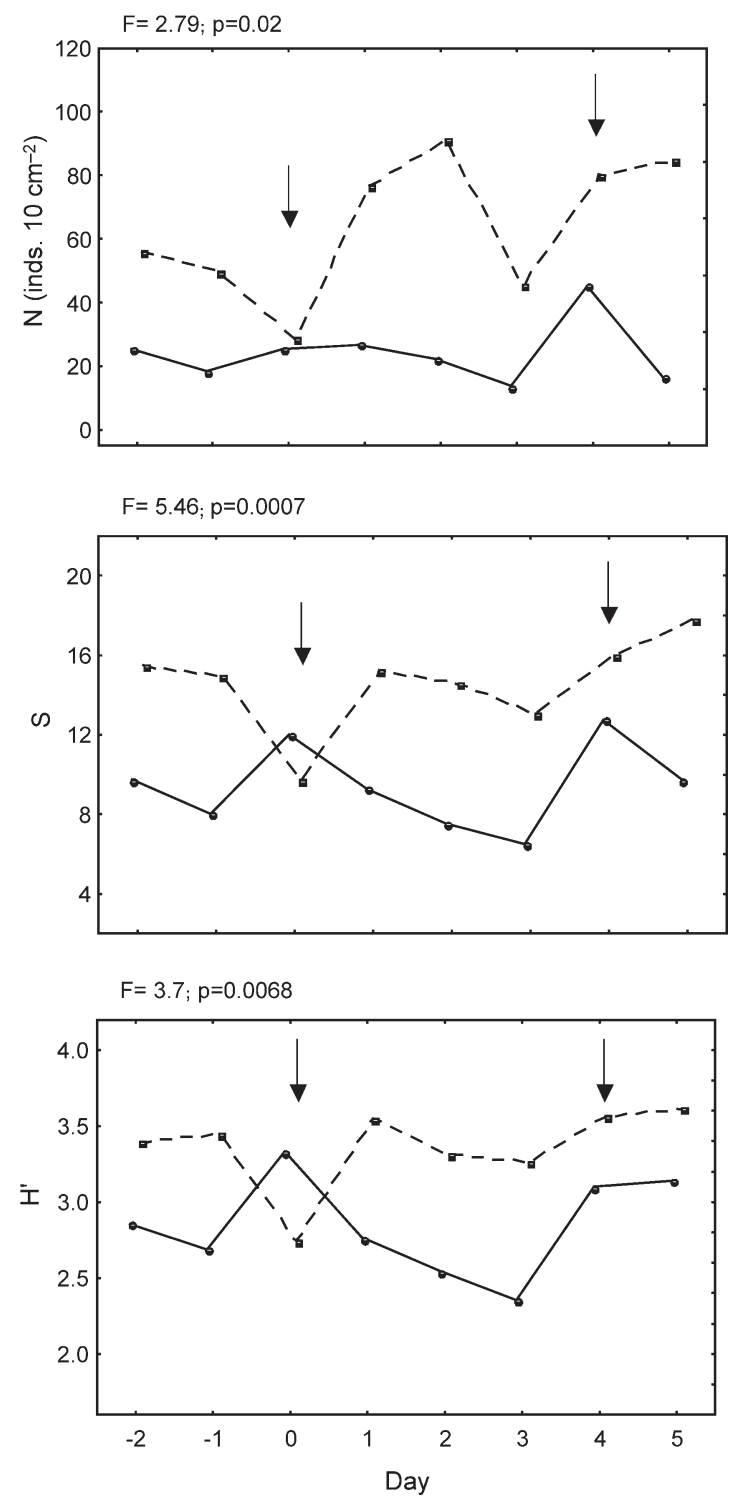

Fig. 11. F-ratios and significance level of 2-way ANOVA interaction tests between Days and sediment strata, and means for univariate measures derived from data on nematodes in the upper (dashed lines) and lower stratum (ful lines). Arrows indicate passage of the cold fronts. $\mathrm{N}=$ total density, $\mathrm{S}=$ number of genera, $\mathrm{H}^{\prime}$ = Shannon-Wiener diversity

and benthic systems were examined by the BIO-ENV procedure (Table 1). The highest correlations were found for the meiofauna. Seston concentration, predominant wind direction and southerly wind velocity were the variables that best explained the variations in the structure of the benthic fauna.

\section{DISCUSSION}

Shallow-water coastal systems are subjected to a variety of natural episodic events which differ in predictability, frequency, and intensity. Significant
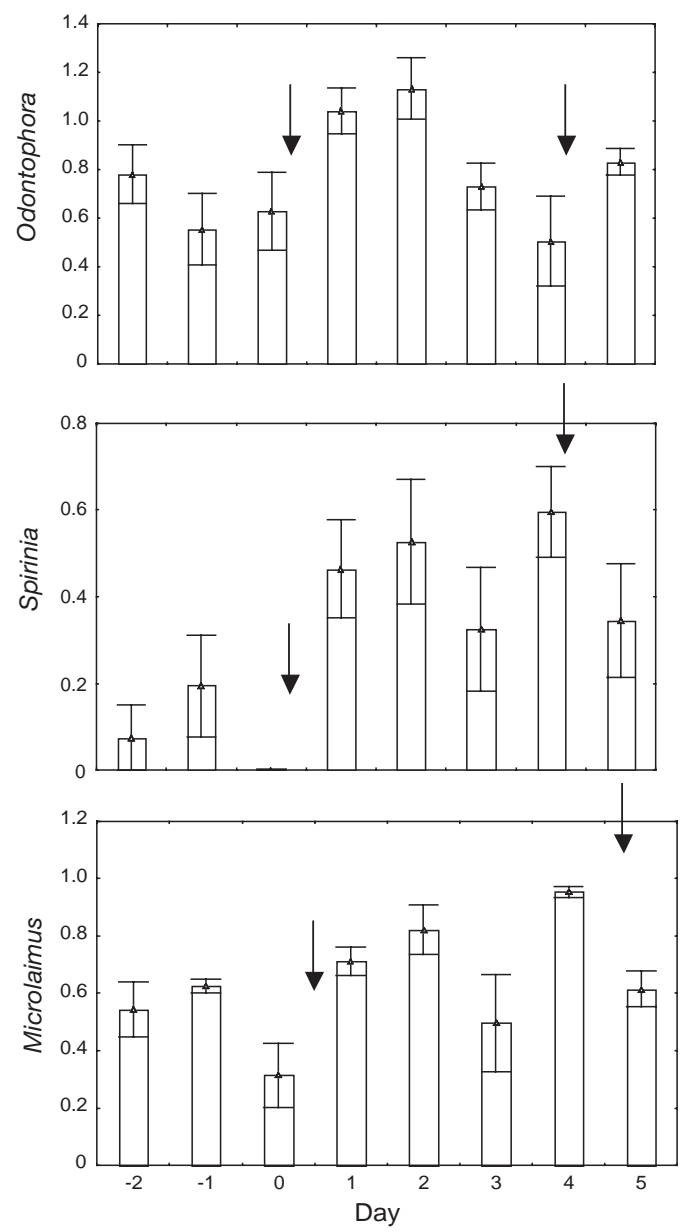

Fig. 12. Densities $(\log (x+1)$; mean $\pm \mathrm{SE})$ of the nematode genera Odontophora, Microlaimus and Spirinia in the upper stratum. Arrows indicate passage of the cold fronts

changes in the pelagic and benthic systems have been attributed to unusual climatic events, such as major storms that lead to homogenization of the water column and movement in the bulk sediment (Dobbs \& Vozarik 1983) or to unpredictable changes in wind stress (De Jonge \& Van Beusekom 1995). However, the results of this study show that predictable short-term meteorological events of high-frequency - the passage of cold fronts - play a significant role in structuring both the pelagic and benthic systems.

In the pelagic system, both cold fronts changed seston, nutrient and chl a concentrations. Short-term variations in concentration of seston and chl $a$ in shallow water systems have been attributed to waves induced by episodic winds (De Jonge \& Van Beusekom 1995, Huang et al. 2003). The increase in chl a concentration just after the cold fronts probably resulted from the action of the southerly winds: phytoplankton retention and accumulation inshore, higher availability of nutrients, and microphytobenthos resuspension. 


\section{a Total}
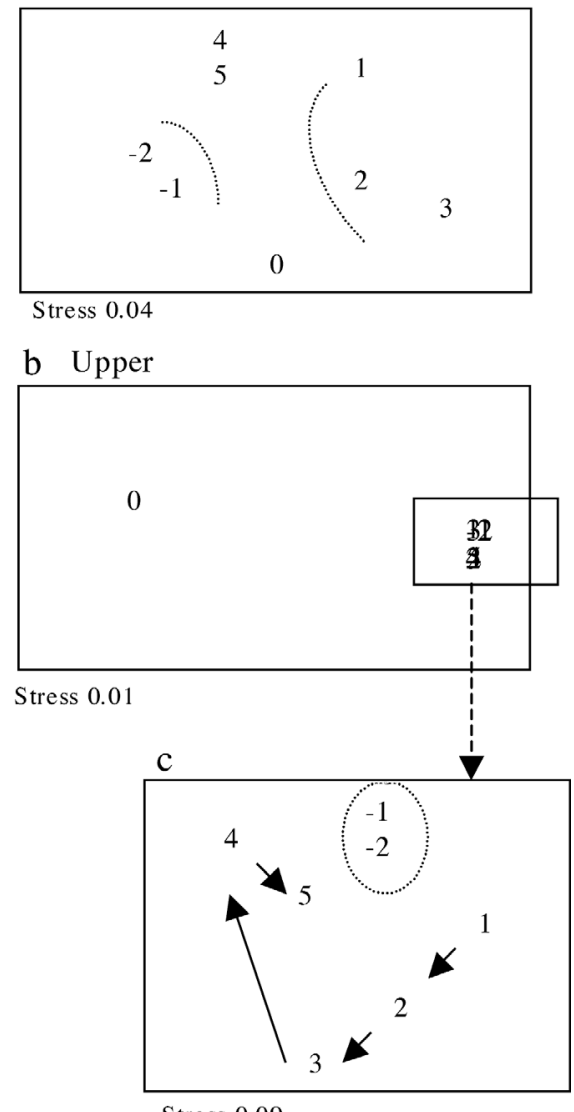

d Lower

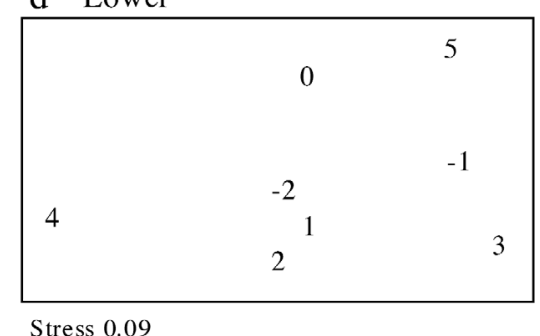

Fig. 13. MDS ordination for transformed nematode abundances: (a) $10 \mathrm{~cm}$ integrated sediment, (b) upper stratum, (c) second-stage MDS of the upper stratum, and (d) lower stratum

The high temperatures and calm weather preceding the passage of cold fronts favour nearshore growth of phytoplankton cells. In the South Brazil Bight, SW winds bring a reversal in the flow of superficial waters pushing onshore more haline waters from offshore (Stech \& Lorenzetti 1992). Thus, the action of strong onshore winds that occurred during the passage of the fronts, together with higher turbulence offshore, promoted the retention and accumulation of cells in shallow areas, as also observed by Odebrecht et al. (1995a,b).

Turbulent stresses affect the physical structure of the sediment-water interface and may enhance the trans-

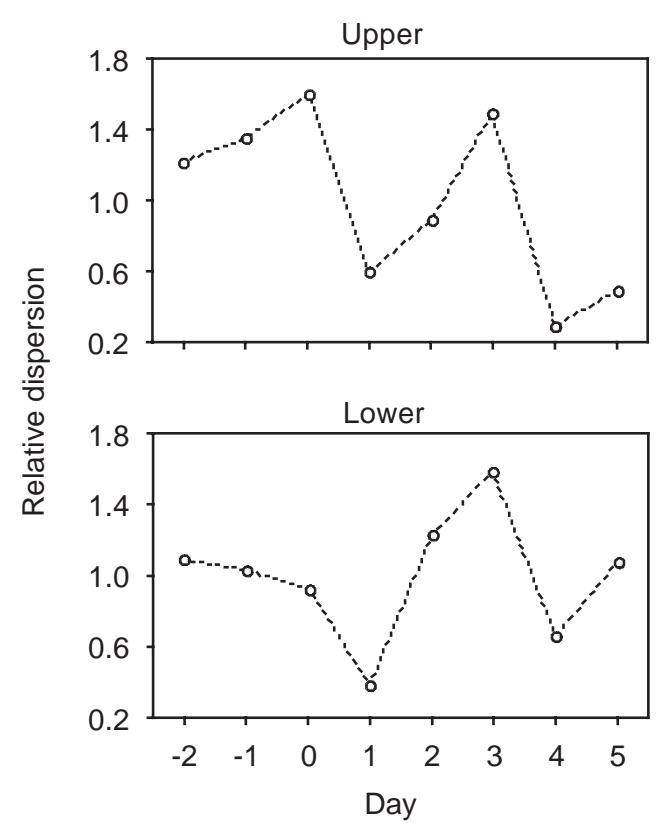

Fig. 14. Multivariate relative dispersion index for nematode abundances in the upper and lower strata

fer of dissolved constituents from the upper parts of the sediment column (Rhoads et al. 1975, De Jonge \& Van Beusekom 1995; De Jonge 2000). The increase in silicate and phosphate concentrations on the same day as the highest seston values (Day 0) suggests that an input of these nutrients into the water column may have contributed to diatom reproduction. In addition, together with the increase in chl a concentrations on Days 1 and 4, reductions in both silicate and total nitrogen were also observed, suggesting that these nutrients were consumed.

Microphytobenthos resuspension may have also contributed to the increase in chl a after the passage of the cold fronts. Turbulence generated by strong winds can promote an increase in chl a concentrations by resuspending the sediments and introducing diatom cells and resting spores into the water column (Brandini \& Rebello 1994, De Jonge \& Van Beusekom 1995, De Jonge 2000). De Jonge \& Van Beusekom (1995) showed that the percentage of benthic chl a present in water, as well as the resuspended fraction of microphytobenthos from the sediment, can be described as a linear function of wind speed. Sediment chl a concentrations in this study were significantly lower after the passage of both fronts. During the passage of the first front, the southerly winds had a mean velocity of $6.4 \mathrm{~m} \mathrm{~s}^{-1}$, which according to Underwood (1993) and De Jonge \& Van Beusekom (1995) is strong enough to disrupt the microphytobenthic layer. After the passage of the fronts, sediment deposition would have contributed to the reduction in microphytobenthos. 
a

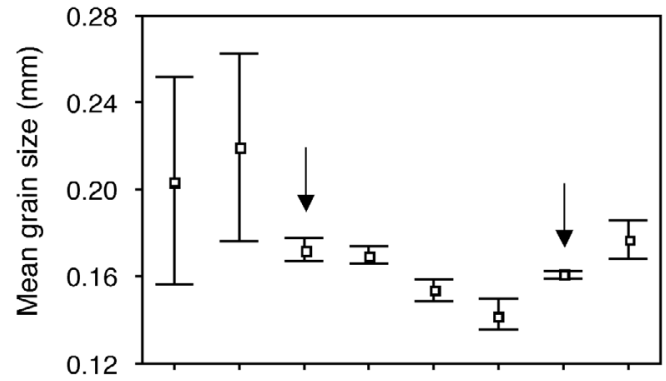

b

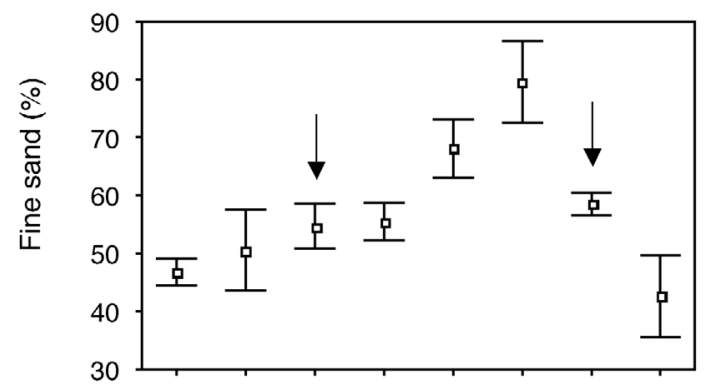

C

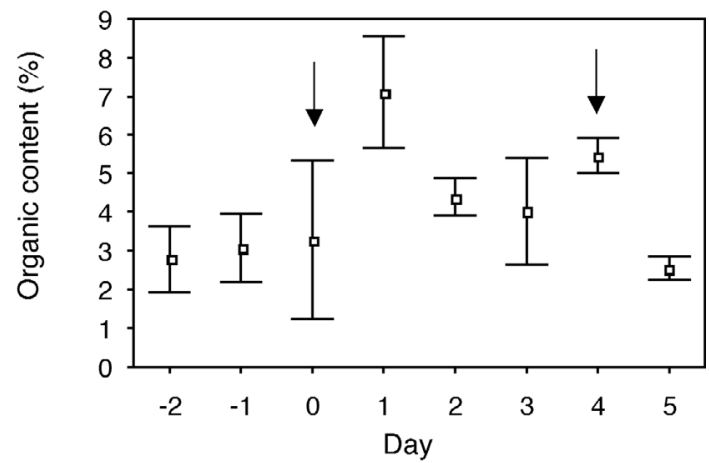

Fig. 15. (a) Grain size, (b) fine sand percentage and (c) sediment organic content (mean $\pm \mathrm{SE}$ )

Together with the reduction in sediment $\operatorname{chl} a_{\text {, }}$ higher phaeopigment concentrations were registered just after the passage of both fronts (Days 1 and 5). This increase indicates a higher decomposition rate on these days. The deposition of dead cells derived from the phytoplankton and resuspended diatoms, added to the burial of benthic diatom cells must have enhanced decomposition processes.

Meio- and macrofauna in the upper $5 \mathrm{~cm}$ of the sediment showed a decrease in densities during the passage of the first front. Total number of nematode genera and of macrofauna taxa also declined. Small, surface-living fauna are likely to be buried or washed away by turbulence. Larger and deeper-burrowing organisms adapted to withstand pe-

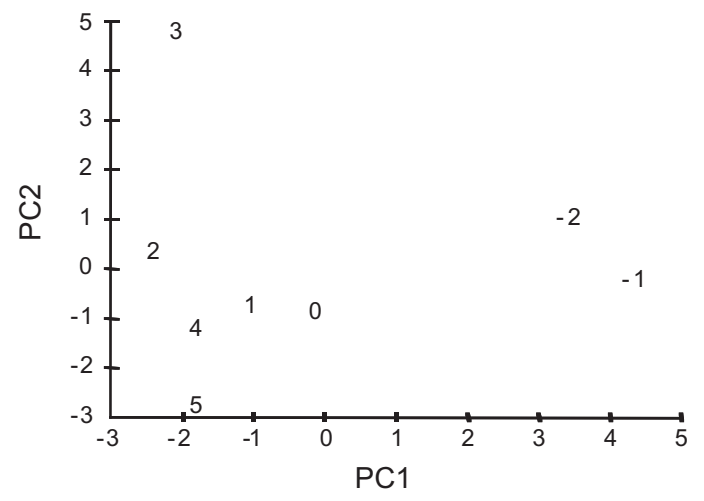

Fig. 17. Ordination of sampling days by a correlation-based principal component analysis of atmospheric, pelagic and benthic environmental variables

riodic erosion and burial are likely to survive (Turner et al. 1995). The results of this study suggested that both processes-resuspension and vertical migration occurred during the passage of the first front.

Small benthic organisms are subjected to the same erosion/suspension processes that act on sediments (Palmer \& Gust 1985). Adult and juvenile meiofauna is regularly found in the water column (Palmer 1988). However, despite their high densities in sediments, nematodes occur in comparatively low abundances in the water column (Palmer 1998). In this study, when analyzing both upper and lower strata together $(10 \mathrm{~cm}$ integrated), nematode density significantly decreased during the passage of the front, indicating that the turbulent flow caused by strong southerly winds resuspended these organisms. Nonetheless, resuspension of meiofauna was restricted to the top few centimetres of the sediment. Contrary to the upper $5 \mathrm{~cm}$ the lower sediment stratum exhibited an increase in diversity and in the number of taxa on the day of the passage of the first front. This suggests that the turbulence gener-

Table 1. Results of BIO-ENV. Combinations of environmental variables yielding the best match of biotic and abiotic matrices, as measured by Spearman rank correlation $\left(\rho_{\mathrm{w}}\right)$

\begin{tabular}{|c|c|c|}
\hline Sediment stratum & Best combination of variables & $\rho_{\mathrm{w}}$ \\
\hline Macrofauna & Seston, predominant wind, medium sand & 0.37 \\
\hline \multicolumn{3}{|l|}{ Meiofauna } \\
\hline Total & Coarse sand, gravel & 0.7 \\
\hline Upper & $\begin{array}{l}\text { Predominant wind, southern wind } \\
\text { velocity, gravel }\end{array}$ & 0.53 \\
\hline Lower & Seston, medium sand & 0.56 \\
\hline \multicolumn{3}{|l|}{ Nematode } \\
\hline Total & Seston, predominant wind, gravel & 0.31 \\
\hline Upper & Southern wind velocity, coarse sand, gravel & 0.37 \\
\hline Lower & $\begin{array}{l}\text { Seston, predominant wind, temperature, } \\
\text { medium sand }\end{array}$ & 0.34 \\
\hline
\end{tabular}


ated by the passage of the frontal system may promote vertical migration of nematodes from the upper to the deeper layers of the sediment. Although the total number of taxa in the upper stratum was significantly lower on the day of the passage of the front, the total number of taxa in both strata combined remained constant. These results are consistent with the hypothesis of Palmer \& Molly (1986) that nematodes decrease their susceptibility to passive erosion by behavioural responses such as vertical migration. Laboratory experiments have also shown vertical migration of nematodes with increase in water flow (Rhoads et al. 1977, Palmer \& Molly 1986). Until now, however, in situ vertical migration of nematodes had only been observed in intertidal zones (Boaden \& Platt 1971, Joint et al 1982, Fegley 1987, Steyaert et al. 2001).

It is possible that the macrofauna suffered both processes - resuspension and vertical migration. Tamaki (1987) reported that the genus Armandia, the most abundant organism of the macrofauna in this study, inhabits only the top $1 \mathrm{~cm}$ of the sediment, thus being susceptible to resuspension by waves. However, our sampling was not sufficient to confirm which process was responsible for the reduction in macrofauna density during the passage of the first front.

As the wind shifted to NE, turbulent flows ceased and sediment recolonization occurred rapidly. One day after the passage of the front both meiofauna and macrofauna had recovered. However, whilst the macrofauna remained constant until Day 5, the meiofauna exhibited significant oscillations in density. These different patterns in the colonization process are probably due to the high diversity and low dominance in the meiofauna at the sampling site, as compared to the macrofauna. In this study, whilst the macrofauna was largely dominated by only 2 species of polychaetes, the meiofauna was constituted by 45 genera of nematodes which showed low dominance values.

A primary effect of disturbance is the opening of space, allowing the establishment of other individuals. This space is usually associated with a change in the availability of other resources (Pickett \& White 1985; Sousa 2001). After the passage of the first cold front, the nematodes not only rapidly recolonized the sediments but also reached densities higher than those registered before the disturbance. This increase in density is most probably related to the microhabitat created by the deposition of material rich in organic matter (dead cells, mucus, organic detritus), after the passage of the frontal system. The meiofauna, particularly nematodes, show a high efficiency in exploiting the microhabitat created by the presence of detritus (Netto \& Gallucci 2003).

Two days after the passage of the first cold front, nematode densities were similar to those recorded at the beginning of the study. The rapid consumption of resources and the lack of a new input of same magnitude probably limited nematode density. However, although there was a significant decrease in density, there was no loss of genera, so the result was a reduction in some population sizes. The population density of the genera Odontophora, Microlaimus and Spirinia, for example, increased just after passage of the front, but 2 d later returned to initial levels. This suggests an adaptative response of these organisms to the intermittent availability of space and resources.

Depending on the scale of the disturbances, environmental heterogeneity can either increase or decrease (Pickett \& White 1985). Because disturbance events are unevenly distributed in space and time, a mosaic of patches is generated at different stages in a successional sequence. The characteristics of such mosaics will depend on the spatial scale and level of disturbance (type, frequency and intensity) and the subsequent rate and character of the community response as recovery proceeds (Hall 1994). In our study, the reduction in the variability of nematode composition among samples and the drastic decrease in the SE of the mean grain size just after the passage of the cold front showed that the environment suffered a homogenizing process. Environmental patchiness, responsible for the higher variability present in the study area before the disturbance, was probably erased by turbulence. The variability in the community structure among samples however, gradually increased as sediment recolonization proceeded.

The effects of turbulent flows generated by the passage of cold fronts in shallow sublittoral systems depend on 2 aspects: (1) Flow intensity - the more intense the cold fronts are, the more intense is the turbulence that affects the bottom. (2) Bottom structure and biological composition. The second cold front differed from the first one in both aspects. The southern wind velocity was lower during the second front. Thus, turbulent flows affecting the bottom were less intense. In the same way, sediment structure and the associated fauna were not the same during the passage of both cold fronts.

Contrary to the pelagic system and the microphytobenthic community that behaved the same way during the passage of both fronts, the benthic fauna exhibited a different response to the passage of the second cold front. Both meio- and macrofauna showed an increase in density and number of taxa with the passage of the second front. Short-term climatic disturbances can affect the bottom not only by promoting mortality of benthic organisms but also by translocating these organisms and changing the microbial and chemical characteristics of the sediment, as surface sediments are eroded in one place and deposited in another 
(Dobbs \& Vosarick 1983). The increase in density and number of taxa of both meio- and macrofauna with the passage of the second front could actually be a delayed effect of the first front, as sediment deposition was slow and gradual. Sediment mean grain size decreased, reaching values lower than in the period before the first front, suggesting that material from other localities may have been deposited. In the same way, the deposition of benthic organisms transported from other localities to the study site was probably a slow process and may have been the responsible for the increase in density and number of taxa of both meio- and macrofauna a few days after the passage of the first frontal system.

Large-scale transportation of sediment and associated fauna due to wind-induced waves or tidal currents has been reported as a likely determinant of short-term temporal variations in local community composition (Armonies 2000); 3 d after a storm, Dobbs \& Vosarick (1983) recorded benthic species in the water column that were not found in the benthos of the area before the event. They suggested fauna from more exposed locations, where storm effects were more intense, were transported and accumulated at the study site. The occurrence of Dorvillidae, Maldanidae and Onuphidae polychaetes in the macrofauna and the nematode genera Bathylaimus, Choniolaimus, Epacanthion, Praeachanthoncus and Rhips in the meiofauna after the second cold front may be evidence of transport resulting from the first storm. These organisms probably came from nearby beaches or deeper zones of the study area.

Acknowledgements. We are indebted to the CLIMERH team, especially Dr Patrícia Sunyé; this would have been impossible without her engagement, dedication and suggestions. We thank Gustavo Fonseca for help during sampling, and Elisabeth Braga from IO-USP for the water analyses. We also thank to Dr. Eduardo Sierra, Simão Simonassi and Alessandra Fonseca from NEMAR, for providing facilities for microphytobenthos analysis. We deeply appreciate Arante's - Pântano do Sul - for help during the sampling period, particularly during the passage of the front. The manuscript benefitted from the comments of 3 anonymous referees.

\section{LITERATURE CITED}

Armonies W (2000) On the spatial scale needed for benthos community monitoring in the coastal North Sea. J Sea Res 43:121-133

Boaden PJS, Platt HM (1971) Daily migration patterns in an intertidal meiobenthic community. Thal Jugosl 7:1-12

Brandini FP, Rebello J (1994) Wind field effect on hydrography and chlorophyll dynamics in the coastal pelagial of Admiralty Bay, King George Island, Antarctica. Antartic Sci 6(4):433-422

Carver RE (1971) Procedures in sedimentary petrology. John Wiley \& Sons, New York

Clarke KR, Green RH (1988) Statistical design and analysis for a 'biological effects' study. Mar Ecol Prog Ser 46: 226-231

Clarke KR, Ainsworth M (1993) A method of linking multivariate community structure to environmental variables. Mar Ecol Prog Ser 92:205-219

Clarke KR, Warwick RM (1994) Change in marine communities: an approach to statistical analysis and interpretation. Natural Environment Research Council, Plymouth

De Jonge VN (2000) Importance of temporal and spatial scales in applying biological and physical process knowledge in coastal management, an example for the Ems estuary. Cont Shelf Res 20:1655-1686

De Jonge VN, Bouwman LA (1977) A simple density separation technique for quantitative isolation of meiobenthos using the colloidal silica Ludox-TM. Mar Biol 42:143-148.

De Jonge VN, Van Beusekom JEE (1995) Wind and tideinduced resuspension of sediment and microphytobenthos from tidal flats in the Ems estuary. Limnol Oceanogr 40: 766-778

Dobbs FC, Vozarik JM (1983) Immediate effects of a storm on coastal infauna. Mar Ecol Prog Ser 11:273-279

Fegley SR (1987) Experimental variation of near-bottom current speeds and its effects on depth distribution of sandliving meiofauna. Mar Biol 95:183-191

Hall JS (1994) Physical disturbance and marine benthic communities: life in unconsolidated sediments. Oceanogr Mar Biol Ann Rev 32:179-239

Huang SC, Kreeger DA, Newell RIE (2003) Tidal and seasonal variation in the quantity and composition of seston in a North American, mid-Atlantic salt-march. Estuar Coast Shelf Sci 56:547-560

Joint IR, Gee JM, Warwick RM (1982) Determination of finescale vertical distribution of microbes and meiofauna in an intertidal sediment. Mar Biol 72:157-164

Lorenzen CJ (1967) Determination of chlorophyll and phaeopigments: spectrometric equations. Limnol Oceanogr 12: 343-346

Netto SA, Gallucci F (2003) Meiofauna and macrofauna communities in a mangrove from the Island of Santa Catarina, South Brazil. Hydrobiologia 505:159-170

Odebrecht C, Rörig L, Garcia VM, Abreu PC (1995a). Shellfish mortality and red tide event in southern Brazil. In: Lassus P, Arzul G, Erard-le Denn E, Gentien P, Marcailloule Baut C (eds) Harmful marine algal blooms. Lavoisier, Paris, p 213-218

Odebrecht C, Segatto AZ, Freitas CA (1995b). Surf-zone chlorophyll a variability at Cassino Beach, Southern Brazil. Estuar Coast Shelf Sci 41:81-90

Palmer MA, Gust G (1985) Dispersal of meiofauna in a turbulent tidal creek. J Mar Res 43:179-210

Palmer MA, Molly RM (1986) Water flow and vertical distribution of meiofauna: a flume experiment. Estuaries 9(3): $225-228$

Palmer MA (1988) Dispersal of marine meiofauna: a review and conceptual model explaining passive transport and active emergence with implications for recruitment. Mar Ecol Prog Ser 48:81-91

Picket STA, White PS (1985) The ecology of natural disturbances and patch dynamics. Academic Press, London

Rhoads DC, Aller RC, Goldhaber (1977) The influence of colonizing benthos on physical properties and chemical diagenesis of the estuarine seafloor. In: Coull BC (ed) Ecology of marine benthos. University of South Carolina Press, Columbia, SC, p 113-138

Rhoads DC, Tenore K, Browne M (1975) The role of resuspended bottom mud in nutrient cycles of shallow embayments. In: Cronin LE (ed) Chemistry, biology, and the estu- 
arine system, vol. 1. Academic Press, San Diego, CA, p 563-579

SCOR-UNESCO (1966) Determination of photosynthetic pigments in seawater. Monographs on oceanographic methodology, UNESCO, Paris, 1:11- 18

Sokal RR, Rohlf FJ (1997) Biometry (3rd edn). Freeman, New York

Somerfield PJ, Rees HL, Warwick RM (1995) Interrelationships in community structure between shallow-water marine meiofauna and macrofauna in relation to dredging disposal. Mar Ecol Prog Ser 127:103-112

Somerfield PJ, Warwick RM (1996) Meiofauna in marine pollution programmes. A laboratory manual. MAFF Directorate of Fisheries Research, Lowestoft

Sousa WP (2001) Natural disturbance and dynamics of marine benthic communities. In: Bertness MD, Gaines SD, Hay ME (eds) Marine community ecology. Sinauer Associates, Sunderland, MS

Stech JL, Lorenzzetti JA (1992) The response of the South Brazil Bight to the passage of wintertime cold fronts. J Geoph Res 97(C6):9507-9520

Stech JL (1990) Um estudo comparativo da dinâmica da circulação de inverno entre as plataformas continentais das costas sudeste do Brasil e dos Estados Unidos utilizando um modelo numérico. $\mathrm{PhD}$ thesis, Instituto Oceanográfico, University of São Paulo

Steyaert M, Herman PMJ, Moens T, Widdows J, Vincx M

Editorial responsibility: Otto Kinne, Oldendorf/Luhe, Germany
(2001) Tidal migration of nematodes on an estuarine tidal flat (the Molenplaat, Schelde Estuary, SW Netherlands). Mar Ecol Prog Ser 224:299-304

Strickland JHD, Parsons TR (1972) A practical handbook of seawater analysis (2nd ed). Fisheries Research Board of Canada, Ottawa

Suguio K (1973) Introdução à sedimentologia. Edgard Blucher/EDUSP, São Paulo

Sunyé PS (1999) Effet de la variabilité climatique régionale sur la pêche de la sardinelle le long de la côte sud-est du Brasil (1964-1993). PhD thesis, Université de Bretagne Occidentale, Institut Universitaire Européen de la Mer

Tamaki A (1987) Comparison of resistivity to transport by wave action in several polychaete species on an intertidal sand flat. Mar Ecol Prog Ser 37:181-189

Turner SJ, Thrush RD, Pridmore JE, Hewitt VJ (1995) Are soft-sediment communities stable? An example from a windy harbour. Mar Ecol Prog Ser 120:219-230

Underwood GJC, Paterson DM (1993) Seasonal changes in diatom biomass, sediment stability and biogenic stabilization in the Severn Estuary. J Mar Biol Assoc UK 73: 871-887

Varejão-Silva MA (2001) Meteorologia e climatologia. Instituto Nacional de Meteorologia -(INMET), Brasília

Warwick RM, Clarke KR (1993) Increased variability as a symptom of stress in marine communities. J Exp Mar Biol Ecol 172:215-226

Submitted: October 28, 2003; Accepted: July 13, 2004 Proofs received from author(s): October 1, 2004 